\title{
Studi Pendahuluan: E-LKPD Berbasis PBL untuk Meningkatkan Kemampuan Literasi Matematis Peserta Didik
}

\author{
Agus Purnama1, \& Suparman ${ }^{2 *}$ \\ ${ }^{1,2}$ Universitas Ahmad Dahlan, Yogyakarta, Indonesia \\ ${ }^{1}$ SMA Negeri 1 Klaten, Klaten, Indonesia
}

\begin{tabular}{l}
\hline INFO ARTICLES \\
\hline Article History: \\
Received: $11-12-2020$ \\
Revised: $24-12-2020$ \\
Approved: $25-12-2020$ \\
Publish Online: $25-12-2020$ \\
\hline
\end{tabular}

Key Words:

E-LKPD; The Mathematical Literacy Abilities; PBL;

This article is licensed Creative Commons AttributionShareAlike 4.0 International License.

\begin{abstract}
This research aims to find out class XI students' mathematical literacy abilities of SMA Negeri 1 Klaten using Problem Based Learning (PBL) learning model. The type of this research is a qualitative descriptive research which is used a preliminary study (part of the ADDIE stage). The research subjects are class XI students of SMA Negeri 1 Klaten. Data collection instruments use observation guidelines, documentations and interviews. Data is analyzed using Miles Huberman. The low students' mathematical literacy ability is because the applied learning media and learning models have not been able to improve students' mathematical problem-solving skills. The abilities of mathematical literacy in solving problems for subjects with high, average or low academic initial ability is in a very low category.
\end{abstract}

Abstrak: Penelitian ini bertujuan untuk mengetahui kemampuan literasi matematis peserta didik SMA Negeri 1 Klaten kelas XI menggunakan model pembelajaran Problem Based Learning (PBL). Jenis penelitian deskriptif kualitatif sebagai studi pendahuluan (bagian dari tahapan ADDIE). Subjek penelitian adalah peserta didik SMA Negeri 1 Klaten kelas XI. Instrumen pengambilan data menggunakan pedoman observasi, dokumentasi dan wawancara. Data dianalisis dengan menggunakan Miles Huberman. Rendahnya kemampuan literasi matematis peserta didik dikarenakan media pembelajaran dan model pembelajaran yang digunakan belum dapat meningkatkan kemampuan pemecahan masalah matematika peserta didik. Kemampuan literasi matematika dalam memecahkan masalah untuk subyek dengan kemampuan awal akademik tinggi, sedang, maupun rendah berada pada kategori sangat kurang.

Correspondence Address: Kampus 2 UAD Jl. Pramuka No. 42, Sidikan, Umbulharjo, Yogyakarta 55161, Indonesia; e-mail: suparman@pmat.uad.ac.id

How to Cite (APA $6^{\text {th }}$ Style): Purnama, A., \& Suparman, S. (2020). Studi Pendahuluan: E-LKPD Berbasis PBL untuk Meningkatkan Kemampuan Literasi Matematis Peserta Didik. JKPM (Jurnal Kajian Pendidikan Matematika), 6(1): 131-140.

Copyright: 2020 Agus Purnama, Suparman Suparman

Competing Interests Disclosures: The authors declare that they have no significant competing financial, professional or personal interests that might have influenced the performance or presentation of the work described in this manuscript. 


\section{PENDAHULUAN}

Gerakan reformasi matematika pada 1980-an dan 1990-an mengajukan standar baru dalam pendidikan matematika. Dewan Nasiobal Guru Matematika, Asosiasi Matematika dari Amerika dan Dewan Riset Nasional menyoroti pentingnya memiliki kedalaman dan pemahaman yang saling berhubungan dari konsep, prosedur, dan prinsip matematika yang hanya menghafal rumus dan mereproduksi algoritma. Pemahaman lengkap tentang matematika membutuhkan tidak hanya pengetahuan tentang konsep matematika, aturan, dan strukturnya, tetapi juga untuk terlibat dalam proses berpikir matematis, yang meilnbatkan penalaran, memecahkan masalah terbuka, menghubungkan ide-ide matematika, membuat kesimpulan dari data dan mengkomunikasikan matematika ke pelajaran lainnya (Kitcer, 1984). Baru-baru ini bertahun-tahun, beberapa kemajuan telah dibuat dalam hal sistem penilaian sedemikian rupa, yang mereka tangani kompleksitas berpikir matematis dan pemecahan masalah lebih teliti.

Untuk mengatasi tuntutan kehidupan modern, orang perlu memperoleh sejumlah keterampilan yang sering disebut sebagai keterampilan abad ke-21, seperti keterampilan berpikir kritis, keterampilan komunikasi dan kolaborasi, keterampilan sosial dan lintas budaya, dan literasi informasi. Karakteristik kunci dari era abad ke-21 adalah penggunaan besar-besaran teknologi informasi dan komunikasi yang mengarah pada akses mudah ke banyak informasi. Oleh karena itu, untuk menghadapai tantangan abad ke-21, orang perlu menguasai berbagai keterampilan berpikir fungsional dan kritis terkait dengan informasi, meia dan teknologi. Salah satunya keterampilan yang disebut literasi informasi.

Kemampuan untuk memecahkan masalah dalam bentuk soal cerita sebagai bagian dari literasi matematika harus dimiliki setiap peserta didik. Karena, kemampuan tersebut tidak hanya digunakan untuk memecahkan konsep matematika, menjawab pertanyaan bahwa pembelajaran hanya membutuhkan aspek kognitif, tetapi digunakan oleh peserta didik untuk menyelesaikan semua masalah dalam kehidupannya, yang melibatkan berbagai unsur kompleks dan berbagai masalah. Karena itu, kemampuan ini dirasa penting untuk dikuasai oleh peserta didik. Tetapi pada kenyataannya, kompetensi keterampilan pemecahan masalah belum dikuasai oleh peserta didik.

Ketika peserta didik kurang mampu memahami soal yang diberikan, maka akan terjadi kesalahan dalam membuat rencana yang akan diterapkan dalam menyelesaikan masalah. Sehingga akan menghasilkan jawaban yang salah. Hal yang sama juga terjadi pada peserta didik SMA Negeri 1 Klaten.

Sejumlah studi menunjukkan bagaimana kegiatan kelas dapat mefasilitasi pengembangan literasi informasi. Menurut OECD dalam (Ananiadou \& Claro, 2009), pemecahan masalah dapat mengembangkan literasi informasi karena sebagian besar melibatkan mendefinisikan, mencari, mengevaluasi, memilih, mengorganisir, menganalisis, dan menafsirkan informasi. Hasil PISA menunjukkan bahwa literasi informasi sejalan dengan praktik matematika yang melibatkan membangun argumen dan mengkritik alasan orang lain dan mencari dan mengekspresikan keteraturan dalam penalaran berulang. Seperti itu masalah yang mengharuskan peserta didik untuk memahami masalah yang sebenarnya dan untuk membuat model berdasarkan kenyataan untuk yang membutuhkan seperangkat kompetensi. Kompetensi ini mencakup kemampuan untuk mengenali kuantitas dirujuk oleh atau dimasukkan dalam situasi dan untuk mencari informasi yang tersedia dan untuk me-review antara informasi yang relevan dan tidak relevan (Maass, 2006), yang jelas merupakan karakteristik informasi melek huruf. Menariknya, kompetensi tersebut juga merupakan karakteristik literasi matematika (OECD, 2003). Ini menunjukkan bagaimana literasi informasi dan literasi matematika memiliki karakteristik yang sama. Mempertimbangkan kesamaan antara kedua literasi ini, penelitian ini bertujuan untuk menyelidiki kemampuan literasi matematis peserta didik.

Berdasarkan hasil uraian tes yang diberikan kepada beberapa peserta didik dengan tujuan untuk mengetahui kemampuan memecahkan masalah nyata tentang literasi matematika, diperoleh 
bahwa masih banyak peserta didik yang belum mampu mengidentifikasi masalah, membuat perencanaan masalah, melaksanakan rencana masalah dan memeriksa hasil penyelesaian permasalahan. Dari uraian yang telah dijelaskan, diperlukan tindakan lebih lanjut untuk mengatasi masalah ini dengan menerapkan salah satu model Pembelajaran Berbasis Masalah. Adapun metode pembelajaran yang tepat untuk mengatasi permasalahan di atas dengan menerapakan model pembelajaran Problem Based Learing (PBL).

Penelitian yang dilakukan di SMA Negeri 1 Klaten kali ini bertujuan untuk menelaah materi apa yang masih sulit dipelajari oleh peserta didik, tingkat kemampuan peserta didik untuk memecahkan masalah literasi matematika, model pembelajaran yang tepat untuk meningkatkan kemampuan pemecahan masalah matematika, dan sumber belajar apa yang diperlukan untuk meningkatkan kemampuan pemecahan masalah peserta didik selama belajar daring.

Setelah melaksanakan observasi di SMA Negeri 1 Klaten dapat memberikan hasil bahwa bahwa LKPD yang digunakan oleh guru bukan merupakan hasil dari rancangan guru. LKPD yang digunakan dalam proses pembelajaran menggunakan LKPD yang sudah jadi. Berdasarkan pengamatan yang dilakukan terhadap LKPD, terdapat beberapa kekurangan. Kekurangankekurangan tersebut diantaranya: penyajian materi yang kurang lengkap, tidak adanya uraian indikator, tampilan sampul yang tidak memancing motivasi peserta didik, kegiatan-kegiatan untuk peserta didik kurang tersedia dan soal-soal yang disajikan bukan merupakan soal pengembangan literasi matematis seperti dalam menyelesaikan soal-soal HOTS.

Menurut Khairyah PBL melibatkan peserta yang menyelesaikan masalah yang terjadi dalam kehidupan sehari-hari mereka. Model pembelajaran PBL membantu peserta didik mengembangkan kemampuan untuk menggunakan pengetahuan dasar dalam menyelesaikan masalah-masalah pada kehidupan nyata dan bekerja sama dengan orang lain.

Langkah-langkah pembelajaran dalam model pembelajaran PBL sebagai berikut: 1) Orientasi peserta didik pada masalah; 2) Mengorganisasi peserta didik untuk belajar; 3) Membimbing penyelesaian individu maupun kelompok; 4) Mengembangkan dan menyajikan hasil karya atau kelompok; dan 5) Menganalisis dan mengevaluasi pemecahan masalah. Sumber belajar merupakan bagian penting dalam pelaksanaan pendidikan di sekolah. Karena sumber belajar bisa dijadikan sebagai media pembelajaran dan menjadi pegangan bagi guru dan peserta didik, sumber belajar perlu diorganisir dengan baik agar bermanfaat bagi para peserta didik dan guru. Pengorganisir sumber belajar tersebut bisa melalui suatu rancangan pembelajaran yang dapat dimanfaatkan sebagai sumber belajar. Menurut Depdiknas (2008) lembar kerja peserta didik atau lembar kerja peserta didik merupakan salah satu bahan ajar yang dapat digunakan.

Adapun aktivitas dalam masa pandemi Covid-19, terutama terkait bekerja, belajar dan beribadah yang semua dilakukan dari rumah atau disebut sebagai Work From Home (WFH), sehingga interaksi tatap muka sekarang langsung jelas tidak dilakukan. Guna menyikapi kondisi tersebut maka sumber belajar yang dapat sekaligus dipakai untuk latihan peserta didik adalah LKPD yang berbentuk elektronik atau e-LKPD sehingga dapat diakses seluruh peserta didik dengan lebih interaktif dan menarik, sehingga dapat mengatasi kebosanan selama masa pandemi Covid-19.

Berdasarkan permasalahan tersebut, maka peneliti bermaksud memperbaiki situasi dengan cara mengembangkan e-LKPD berbasis PBL untuk meningkatkan kemampuan literasi matematis peserta didik. kelas XI MIPA SMA Negeri 1 Klaten tahun pelajaran 2020/2021.

\section{METODE}

Metode dalam yang digunakan mengadopsi penelitian Marian \& Suparman (2019), menggunakan model ADDIE (Analysis, Design, Development, Implementation, and Evaluation). Pada penelitian ini, tahapan yang dilaksanakan yaitu analysis yang kemudian ditindaklanjuti dengan design e-LKPD. Mengacu pada analysis yang dilakukan dengan pendekatan kualitatif 
deskriptif. Teknik yang digunakan peneliti adalah Miles Huberman yang terdiri dari reduksi data, penyajian data dan penarikan kesimpulan.

Pada penelitian ini yang menjadi subyek penelitian adalah peserta didik kelas XI SMA Negeri 1 Klaten dengan mengambil 12 subyek. Pengambilan subyek dilakukan dengan Teknik purposive sampling. Subyek yang diambil dengan pertimbangan merupakan perwakilan dari masing-masing kelas program peminatan MIPA, yaitu peserta didik dengan kemampuan tinggi, peserta didik dengan kemampuan sedang, dan peserta didik dengan kemampuan rendah. Instrumen dalam penelitian ini berbentuk tes uraian berupa soal cerita. Materi yang dipakai Turunan Fungsi Aljabar dan Penerapan Turunan fungsi. Di mana instrumen tersebut dipakai dengan tujuan untuk mengetahui kemampuan peserta didik dalam pemecahan masalah literasi matematika.

\section{HASIL}

Kemampuan peserta didik dalam pemecahan masalah matematika bisa dilihat dengan menerapakan indikator yang dikemukakan Polya dalam (Orton, 2004: 86): 1) Peserta didik paham terhadap masalah; 2) Peserta didik dapat melakukan penyusunan rencana untuk memecahkan masalah; 3) Peserta didik menggunakan rencana dalam penyelesaian masalah; dan 4) Peserta didik meneliti kembali hasil pemecahan masalah yang telah dilakukan. Setelah peneliti memperoleh data hasil tes peserta didik dalam memecahkan masalah matematika. Data tersebut kemudian dikelompokkan berdasarkan tingkat kemampuan peserta didik, yaitu peserta didik dengan kemampuan tinggi, peserta didik dengan kemampuan sedang dan, peserta didik dengan kemampuan rendah. Kemudian peneliti akan menganalisis tingkat kemampuan pemecahan masalah matematika yang dilakukan peserta didik berdasarkan dengan indikator pemecahan masalah. Berikut penulis tampilkan Gambar 1. merupakan contoh LKPD yang kurang memotivasi peserta didik.

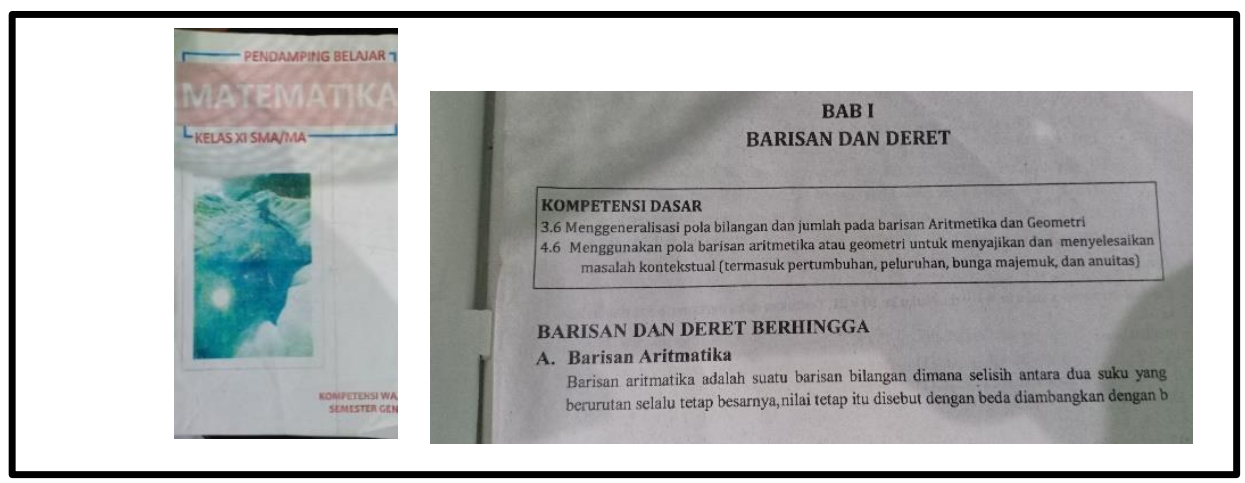

Gambar 1. Contoh LKPD yang Kurang Memotivasi Peserta didik

Setelah peneliti melakukan analisis terhadap kemampuan peserta didik dalam memecahkan masalah matematika pada tiap indikator. Didapatkan nila rata-rata tingkat kemampuan peserta didik dalam memecahkan masalah matematika. Hasil analisis dapat dilihat pada Tabel 1.

Tabel 1. Persentase Nilai Tiap Indikator Kemampuan Peserta Didik dalam Memecahkan Masalah Matematika

\begin{tabular}{ccccc}
\hline No & Indikator Pemecahan Masalah & $\begin{array}{c}\text { Tingkat } \\
\text { Kemampuan } \\
\text { Peserta Didik }\end{array}$ & $\begin{array}{c}\text { Nilai Rata- } \\
\text { Rata }\end{array}$ & Kategori \\
\hline 1. & Pemahaman Masalah & Tinggi & $0 \%$ & $\begin{array}{c}\text { Sangat kurang } \\
\text { Sedang }\end{array}$ \\
& & Sendah & $0,61 \%$ & Sangat kurang \\
& & Tinggi & $0 \%$ & Sangat kurang \\
2. & Perencanan dalam & Sedang & $0 \%$ & Sangat kurang \\
& menyelesaikan masalah & Rendah & $0 \%$ & Sangat kurang \\
\hline
\end{tabular}




\begin{tabular}{|c|c|c|c|c|}
\hline No & Indikator Pemecahan Masalah & $\begin{array}{c}\text { Tingkat } \\
\text { Kemampuan } \\
\text { Peserta Didik }\end{array}$ & $\begin{array}{l}\text { Nilai Rata- } \\
\text { Rata }\end{array}$ & Kategori \\
\hline \multirow{4}{*}{3.} & \multirow{4}{*}{$\begin{array}{l}\text { Menggunakan rencana dalam } \\
\text { menyelesaikan masalah }\end{array}$} & Tinggi & $0 \%$ & Sangat kurang \\
\hline & & Sedang & $0 \%$ & Sangat kurang \\
\hline & & Rendah & $0,36 \%$ & Sangat kurang \\
\hline & & Tinggi & $0 \%$ & Sangat kurang \\
\hline \multirow{2}{*}{4.} & \multirow[t]{2}{*}{ Memeriksa kembali hasil } & Sedang & $0 \%$ & Sangat kurang \\
\hline & & Rendah & $0 \%$ & Sangat kurang \\
\hline
\end{tabular}

Selanjutnya tiap indikator kemampuan peserta didik dijabarkan dalam memecahkan masalah matematika peserta didik

1. Indikator pertama: Peserta didik mampu memahami masalah

Pada indikator untuk memahami masalah. Kita bisa melihat dari Tabel 1., bahwa peserta didik dengan kemampuan tinggi, peserta didik dengan kemampuan sedang, dan peserta didik dengan kemampuan rendah berada pada kategori yang sama yaitu sangat kurang $(0 \%, 0 \%$, $0,61 \%$ ). Ini menunjukkan masih banyak peserta didik yang belum dapat memahami soal yang diberikan terkait apa yang diketahui dan yang ditanyakan.

2. Indikator kedua: Peserta didik mampu membuat rancana pemecahan masalah

Pada indikator membuat rencana pemecahan masalah. Kita bisa melihat dari Tabel 1., bahwa peserta didik dengan kemampuan tinggi, peserta didik dengan kemampuan sedang, dan peserta didik dengan kemampuan rendah berada pada kategori yang sama yaitu sangat kurang $(0 \%, 0 \%, 0 \%)$. Ini menunjukkan dalam menyelesaikan soal, seluruh peserta didik tidak melakukan perencanaan sebelum melakukan pemecahan masalah matematis. Sebagian peserta didik banyak yang ketika melakukan pemecahan masalah matematis hanya mengidentifikasi soal terkait apa yang diketahui dan ditanyakan selanjutnya melakukan perhitungan tanpa perencanaa.

3. Indikator ketiga: Peserta didik mampu melaksanakan rencana pemecahan masalah

Pada indikator pelaksanaan rencana pemecahan masalah. Kita dapat melihat dari Tabel 1., bahwa peserta didik dengan kemampuan tinggi, peserta didik dengan kemampuan sedang, dan peserta didik dengan kemampuan rendah berada pada kategori yang sama yaitu sangat kurang $(0 \%, 0 \%, 0,36 \%)$. Ini menunjukkan banyak peserta didik ketika memecahkan masalah tidak sesuai rencana. Peserta didik masih banyak yang dalam proses pemecahan masalah menggunakan perhitungan dengan benar tetapi hasilnya berbeda, ada juga yang tidak sesuai rumus dalam menyelesaikan masalah.

4. Indikator keempat: Peserta didik mampu memeriksa kembali hasil.

Pada indikator pemeriksaan kembali hasil jawaban. Kita dapat melihat pada Tabel 1., bahwa peserta didik dengan kemampuan tinggi, peserta didik dengan kemampuan sedang, dan peserta didik dengan kemampuan rendah berada pada kategori yang sama yaitu sangat kurang $(0 \%, 0 \%, 0 \%)$. Data ini menunjukkan bahwa seluruh peserta didik dalam memecahkan masalah matematika berupa soal cerita yang diberikan, tidak memeriksa kembali jawaban yang telah dikerjakan. Nilai rata-rata hasil analisis tingkat kemampuan semua peserta didik dalam memecahkan masalah matematis, dikategorikan berdasarkan peserta didik dengan kemampuan tinggi, peserta didik dengan kemampuan sedang dan peserta didik dengan kemampuan rendah disajikan dalam Tabel 2. 
Tabel 2. Nilai Kemampuan Peserta Didik dalam Memecahkan Masalah Matematis

\begin{tabular}{cccc} 
No & Tingkat Kemampuan Peserta Didik & Nilai rata-rata & Kategori \\
\hline 1. & Tinggi & $0 \%$ & Sangat Kurang \\
2. & Sedang & $0 \%$ & Sangat Kurang \\
3. & Rendah & $0,24 \%$ & Sangat Kurang \\
\hline
\end{tabular}

Dari Tabel 2, dapat menunjukkan tingkat kemampuan peserta didik berkemampuan tinggi terdapat di kategori sangat kurang $(0 \%)$. Sama halnya dengan tingkat kemampuan peserta didik berkemampuan sedang terdapat di kategori sangat kurang $(0 \%)$. Demikian juga dengan tingkat kemampuan peserta didik berkemampuan rendah berada pada kategori yang sama dengan peserta didik yang berkemampuan tinggi dan sedang yaitu kategori sangat rendah $(0,24 \%)$. Data ini merupakan gambaran bahwa tingkat kemampuan peserta didik pada saat menyelesaikan masalah matematika tergolong rendah. Hal ini juga menunjukkan ketidakmampuan peserta didik dalam mengaplikasikan indikator kemampuan pemecahan masalah dalam menyelesaikan soal cerita yang diberikan.

Hasil lain yang diperoleh dapat diperinci menjadi: 1) materi Turunan Fungsi Aljabar dan Penerapan Turunan Fungsi masih dianggap sulit oleh peserta didik; 2) kemampuan peserta didik dalam memecahkan masalah literasi matematis masih rendah; 3) model pembelajaran PBL dapat digunakan untuk meningkatkan kemampuan memecahkan masalah literasi matematis peserta didik; 4) E-LKPD yang sesuai karakteristik peserta didik serta terintegrasi dengan kemampuan pemecahan masalah literasi matematis diperlukan oleh guru maupun peserta didik; dan 5) sumber belajar yang sesuai model pembelajaran PBL belum tersedia dan sumber belajar yang menanamkan kemampuan pemecahan masalah literasi matematis peserta didik juga belum tersedia

E-LKPD yang digunakan sebagai sumber belajar sesuai model PBL perlu didesain dan dikembangkan dengan baik. Pendesainan dan pengembangan E-LKPD ditekankan untuk meningkatkan kemampuan literasi matematis dalam pemecahan masalah peserta didik. Hasil ELKPD yang didesain sesuai dengan model PBL diharapkan dapat menjadi salah satu solusi bagi guru dan peserta didik kelas XI SMA Negeri 1 Klaten untuk meningkatkan kemampuan dalam memecahkan masalah.

Setelah melihat hasil dari kemampuan peserta didik SMA Negeri 1 Klaten dalam pemecahan masalah literasi matematis yang diberikan, bisa diperoleh keterangan bahwa tingkat kemampuan peserta didik dalam memecahkan literasi matematis masih rendah. Tindak lanjut yang dilakukan dengan pengembangan bahan ajar berupa e-LKPD, yang dapat membantu peserta didik meningkatkan kemampuan memecahkan masalah literasi matematis dan memotivasi peserta didik selama pandemi Covid-19. Pada awal studi pendahuluan ini, desain produk baru sebatas desain cover, kata pengantar, serta kompetensi inti, kompetensi dasar dan indikator

a. Desain cover

Cakupan pada desain cover meliputi judul e-LKPD (Lembar Kerja Peserta Didik), mata pelajaran, materi matematika berupa grafik fungsi, model pembelajaran PBL, identitas penulis. Desain cover dapat dilihat pada Gambar 2. 


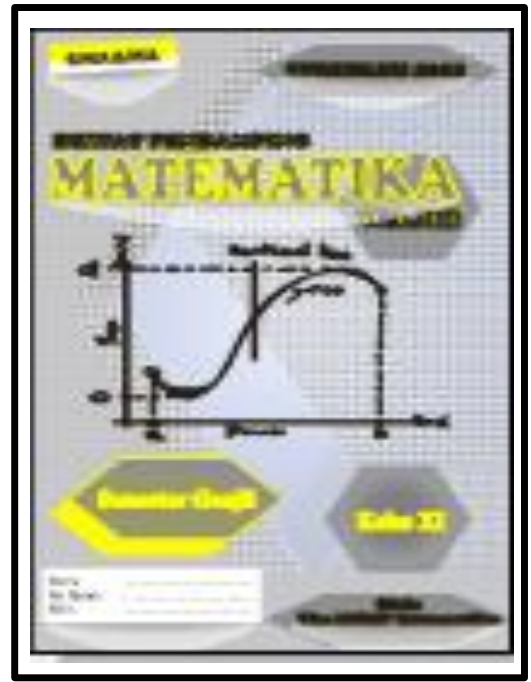

b. Kata pengantar

\section{Gambar 2. Rancangan Cover e-LKPD}

Kata pengantar berisikan ucapan terima kasih dari penulis kepada pihak-pihak yang terlibat dalam pembuatan e-LKPD. Hal terpenting dalam kata pengantar ini memuat penjelasan terkait konten yang termuat di dalamnya. Penjelasan awal ini diharapkan memberikan gambaran bagi guru untuk mendesain proses pembelajaran yang sesuai dengan menggunakan e-LKPD ini. Bentuk gambarnya dapat dilihat pada Gambar 3.

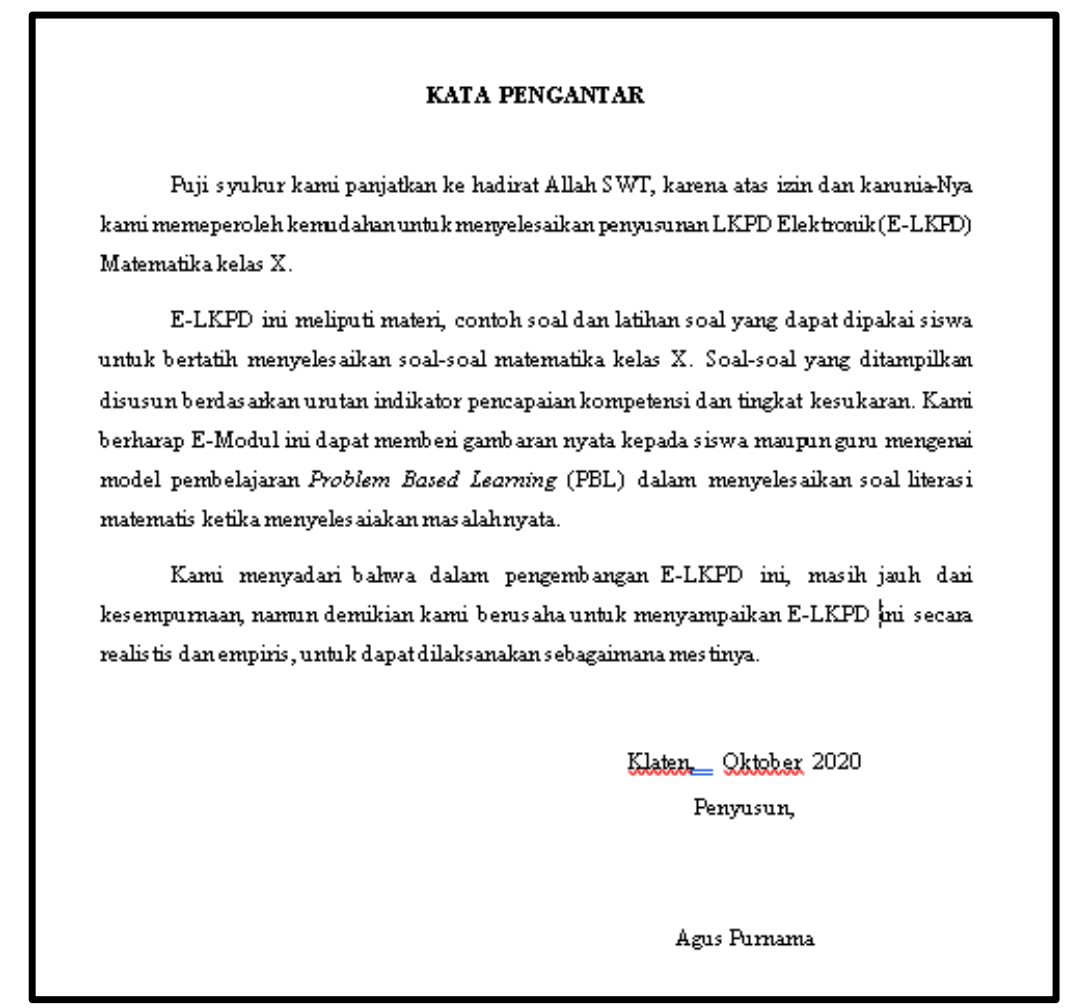

\section{Gambar 3. Kata Pengantar yang Memuat Penjelasan Terkait Konten di Dalam e-LKPD}

c. Kompetensi inti, kompetensi dasar dan indikator

Gambaran dari KI, KD dan indikator pencapaian sebagai tujuan dalam pembelajaran. KI dan KD dapat dilihat pada Gambar 4. Menampilkan KI dan KD menjadi penting sehingga proses pembelajaran dapat terencana dengan baik dari segi penyampaian materi, target 
pertemuan, maupun strategi penyampaiannya. Terlebih dalam situasi pandemi Covid-19, dengan pembelajaran daring proses pembelajaran akan menjadi efektif jika berbasis masalah, dengan PBL sebagai panduannya.

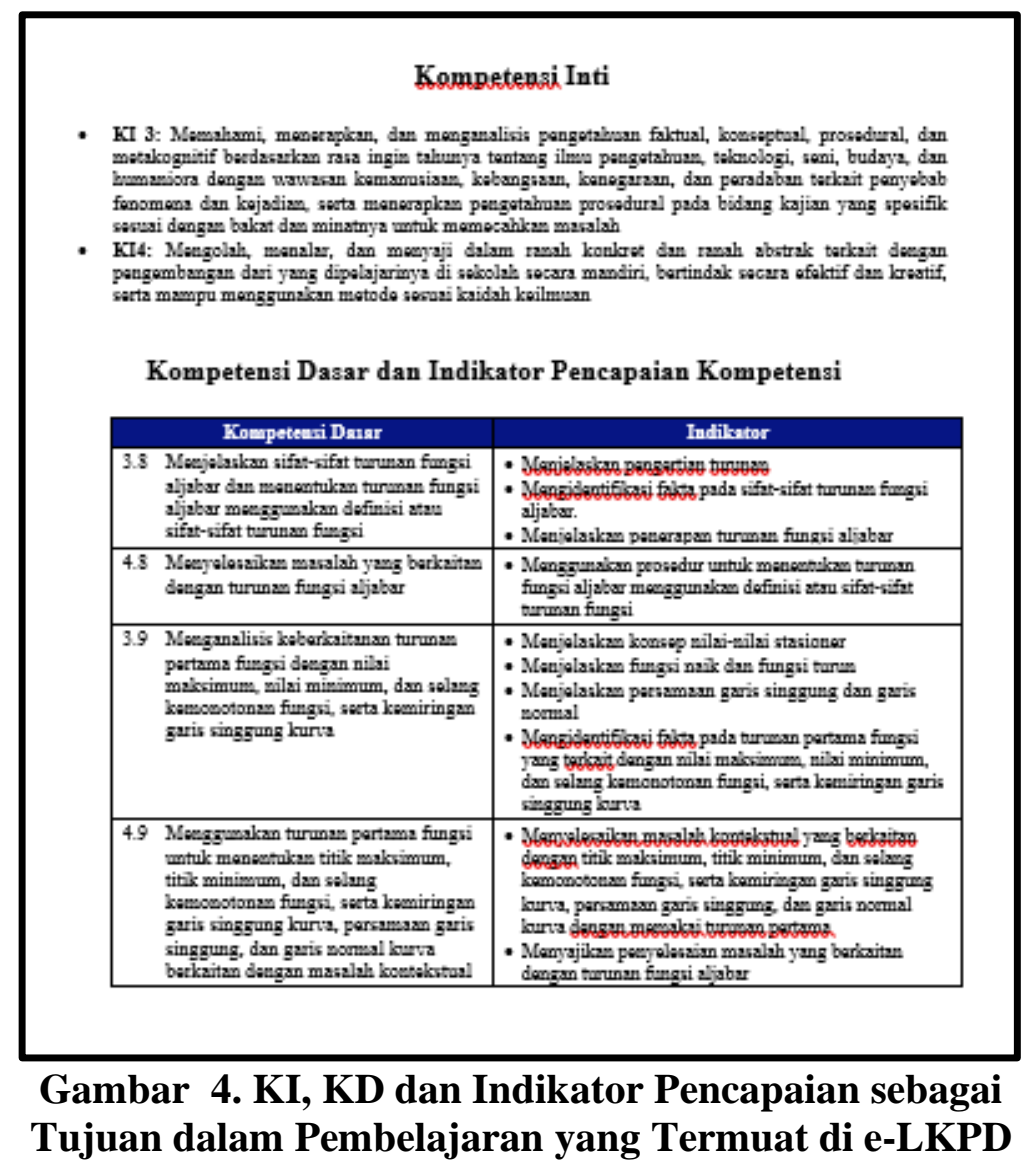

Pada tahapan selanjutnya, dapat dibuat konten pokok dalam e-LKPD termasuk materi, Latihan soal, soal dan pemberian keterangan penerapan prinsip-prinsip pokok PBL dalam proses pembelajaran.

\section{PEMBAHASAN}

Hasil dari studi lapangan yang telah dilakukan dapat memberikan manfaat untuk tahapan selanjutnya, 1) sebagai masukan dalam perbaikan proses belajar dan pembelajaran matematika untuk peserta didik, 2) sebagai dasar untuk mengembangkan e-LKPD sesuai model PBL guna meningkatkan kemampuan literasi matematis dalam menyelesaikan masalah dan meningkatkan prestasi matematika peserta didik kelas XI SMA Negeri 1 Klaten. Khususnya pada poin 2), menjadi focus dalam pengembangan e-LKPD, penerapan model PBL dapat membangkitkan keaktifan peserta didik dalam membentuk konsep matematika dalam dirinya. Terlebih fokus materi Turunan Fungsi Aljabar dan Penerapan Turunan Fungsi, penyajian masalah dapat dikaitkan dengan pengalaman keseharian peserta didik.

Pendekatan berbasis masalah melalui PBL merupakan strategi dalam membangkitkan motivasi peserta didik. Peserta didik dilibatkan untuk aktif dalam menguraikan masalah kemudian menyelesaikannya. Keadaan demikian menjadikan peserta didik tidak hanya sebatas proses menghafal saja, tetapi berpikir untuk menyelesaikan, dan penyelesaiannya merupakan fakta keseharian. Konten seperti inilah nantinya yang perlu ditambahkan dalam e-LKPD. Karena berdasarkan penelitian Budiono, C.S., \& Wardono, W. (2014) membangkitkan motivasi peserta 
didik dalam pembelajaran menjadi hal yang utama, karena motivasi menjadikan perserta didik berfikir alternatif cara penyelesaian lain dalam menyelesaikan masalah yang ada.

Konten dalam e-LKPD sebaiknya dilengkapi dengan penyajian materi prasyarat. Artinya bahwa, ada penguat dasar konsep sebelum masuk dalam inti materi yang disajikan. Masih dalam penelitian Budiono, C.S., \& Wardono, W. (2014), menyebutkan kendala peserta didik lupa terkait materi sebelumnya, padahal materi sebelumnya merupakan dasar dari materi yang sedang disajikan dalam LKPD. Sehingga, untuk menegaskan kompetensi yang ingin dicapai, maka indikator dari aspek konten perlu disebutkan prasayarat yang harus dipenuhi oleh peserta didik.

Fakta lain merujuk pada penelitian Komarudin\& Permana (2019), penyajian dalam e-LKPD penambahan unsur-unsur lain juga memiliki pengaruh. Unsur yang dimaksud dalam penelitian tersebut, memuat kata-kata motivasi, penyajian tampilan warna yang menarik, kemudian adanya emoticon. Dengan tetap pada tujuan awal bahwa e-LKPD dikembangkan mendorong peserta didik untuk belajar secara mandiri. Oleh karena itu e-LKPD harus disajikan lebih menarik karena peserta didik dituntut untuk lebih aktif dalam kegiatan pembelajaran terlebih dalam suasana pandemi Covid-19.

Aspek lain yang perlu diperhaikan adalah syarat didaktik. Hasil temuan Septian, R., Irianto, S., \& Andriani, A. (2019), syarat didaktik pada LKPD menekankan proses untuk menemukan suatu konsep. Proses demikian sejalan dengan model PBL, kegiatan pembelajaran dimulai dengan pemberian masalah oleh guru, kemudian peserta didik menyelesaikan dengan cara mereka sendiri. Tetapi jangan lupa, pada akhir pembelajaran, diberikan penguatan oleh guru, cara-cara seperti apa yang dibenarkan sesuai dengan konsep matematika.

Penelitian-penelitian yang sudah dilakukan, bahan ajar memiliki perubahan salah satunya dari segi pendekatan pembelajarannya. Seperti halnya penelitian Zulfah (2017) menekankan perubahan bahan ajar dilakukan pada segi pendekatan pembelajaran. Dengan adanya perubahan pendekatan pembelajaran, membuat peserta didik untuk aktif dalam mencari dan membangun konsep dari pelajarannya. Secara khusus e-LKPD berbasis PBL tujuan dikembangkan, peserta didik dituntut secara total untuk aktif dalam proses pembelajaran, peserta didik akan dibimbing untuk memecahkan permasalahan yang berkaitan dengan materi pelajaran. Pembelajaran walaupun secara daring, dengan menggunakan e-LKPD berbasis PBL akan memberikan pembelajaran yang bermakna bagi peserta didik. Pada akhirnya, berpegang pada penelitian Yustianingsih, R., Syarifuddin, H., dan Yerizon, Y. (2017), berdasarkan proses pengembangan yang telah dilaksanakan, semestinya diperoleh e-LKPD yang valid, praktis dan efektif untuk meningkatkan kemampuan pemecahan masalah matematis dan aktivitas peserta didik.

\section{SIMPULAN}

Kemampuan literasi matematika dalam memecahkan masalah untuk subyek dengan kemampuan awal akademik tinggi, sedang, maupun rendah berada pada kategori sangat kurang. Dengan demikian penelitian ini dapat ditindaklanjuti dengan mengembangkan bahan ajar e-LKPD dengan model pembelajaran Problem Based Learning (PBL) dalam pembelajaran untuk menstimulus kemampuan pemecahan masalah matematika terutama dalam kemampuan literasi matematis peserta didik.

\section{UCAPAN TERIMA KASIH}

Terima kasih kepada Allah SWT atas rahmat dan karunia-Nya, sehingga penelitian ini dapat diselesaikan dengan baik. Saya juga ingin mengucapkan terima kasih kepada orang tua, keluarga, keluarga, teman-teman MPMAT UAD 2020, dosen MPMAT UAD, validator, bapak kepala sekolah, guru, peserta didik SMA Negeri 1 Klaten dan semua yang tidak dapat kami sebutkan satu per satu. Karena penyelesaian studi ini tidak dapat dipisahkan dari semua dukungan mereka. 


\section{DAFTAR RUJUKAN}

Ananiadou, K., \& Claro, M. (2009). 21st Century Skills and Competences for New Millennium Learners in OECD Countries. OECD Education Working Papers, No. 41. Paris: OECD Publishing

Budiono, C.S., \& Wardono, W. (2014). PBM Berorientasi PISA Berpendekatan PMRI Bermedia LKPD Meningkatkan Literasi Matematika Siswa SMP. Unnes Journal of Mathematics Education, 3(3). https://doi.org/10.15294/ujme.v3i3.4487

Depdiknas, (2008). Panduan Pengembangan Bahan Ajar. Jakarta: Direktorat Pembinaan Sekolah Menengah Atas.

Kitcher, P. (1984). Sifat Pengetahuan Matematika. Oxford: Oxford University Press.

Komarudin, K., \& Permana, P.T. (2019) LKPD Berbasis Scientific Approach terhadap Kemampuan Pemecahan Masalah Peserta Didik Sekolah Dasar. TERAMPIL: Jurnal $\begin{array}{llll}\text { Pendidikan dan Pembelajaran } & \text { Dasar, }\end{array}$ https://doi.org/10.24042/terampil.v6i1.4385

Maass, K. (2006). What are modelling competencies? ZDM Mathematics Education, 38(2), 113142.

Marian, F., \& Suparman. (2019). Design of Student Worksheet Based on Discovery Learning to Improve the Ability of Mathematics Reasoning Students of Class VII Junior High School, J. Phys.: Conf. Ser., 1306(012036) https://iopscience.iop.org/article/10.1088/17426596/1306/1/012036/pdf

OECD. (2003). Kerangka kerja penilaian PISA 2003 - Matematika, membaca, sains, dan masalah memecahkan pengetahuan dan ketrampilan. Paris: OECD

Orton, A. (2004). Learning Mathematics: Issues, Theory and Classroom Practice. UK: A\&C Black

Septian, R., Irianto, S., \& Andriani, A. (2019). Pengembangan Lembar Kerja Peserta Didik (LKPD) Matematika Berbasis Model Realistic Mathematics Education. Jurnal Educatio FKIP UNMA, 5(1), 59-67. https://doi.org/10.31949/educatio.v5i1.56

Yustianingsih, R., Syarifuddin, H., dan Yerizon, Y. (2017). Pengembangan Perangkat Pembelajaran Matematika Berbasis Problem Based Learning (PBL) untuk Meningkatkan Kemampuan Pemecahan Masalah Peserta Didik Kelas VIII. JNPM (Jurnal Nasional Pendidikan Matematika), 1(2), 258-274. http://dx.doi.org/10.33603/jnpm.v1i2.563

Zulfah, Z. (2017). Tahap Preliminary Research Pengembangan LKPD Berbasis PBL untuk Materi Matematika Semester 1 Kelas VIII SMP. Jurnal Cendekia: Jurnal Pendidikan Matematika, 1(2), 1-12. https://doi.org/10.31004/cendekia.v1i2.59 